\title{
Linking Religiosity and Job Performance in Islamic Rural Banks
}

\author{
Aldy Mochammad Faiz Raksayudha ${ }^{\mathrm{a} *}$ and Regina Agustina ${ }^{\mathrm{b}}$ \\ ${ }^{\mathrm{a}}$ Banking Practitioner, Indonesia \\ ${ }^{\mathrm{b}}$ Post Graduate Program of Industrial Engineering and Management, National Yunlin \\ University of Science and Technology, Taiwan
}

Received 10 November 2018; accepted 26 June 2019

\begin{abstract}
Islamic banking is a dynamic segment in the banking industry. However, although having enormous potential, Islamic banks, especially micro banks which have emerged only recently, are perceived as less popular and as less experienced than conventional banking. Therefore, they need a proper strategy to compete and have a high performance compared to their competitors. To conduct this research, 250 Islamic bank employees were gathered using a self-administered questionnaire in West Java Province, Indonesia. This research examines the construct validity and reliability by applying variance-based Structural Equation Modeling (SEM-PLS). This method was used to verify the model that has been proposed. This research shows that Religiosity directly and indirectly affects the job performance in Islamic Rural Bank. This study is also intended to assess the effect of religiosity on job performance through strengthening employee job satisfaction and employee engagement. It also gives a reference for the managers of Islamic Bank that in the recruitment of employees they must also observe their individual religiosity beside their working ability. Then, it needs to be considered and improved to increase their performance and to make it in accordance with the standards expected by the company.
\end{abstract}

\section{KEYWORDS}

Religiosity

Employee engagement

Job satisfaction

Job performance

Islamic bank

\section{INTRODUCTION}

The industry of Islamic banking has a great potential to attract Muslim customers to meet the needs for banking services that are in accordance with the rules of Islamic religion (Muslim, Zaidi, \& Rodrigue, 2013). Besides, it can also attract non-Muslim customers because it is in accordance with the principles carried out by Islamic bank, sharing benefits and risks (Saleh, Quazi, Keating, \& Gaur, 2017). Along with the great potential of Islamic bank, there is also a big challenge for it. The presence of new Islamic banks are less popular and less experienced compared to conventional banks that came earlier in the banking industry (Nizar \& Marzouki, 2015). Therefore, it is important for Islamic Banks to develop the potential of their employees, as the agents who run the business, to make them work professionally based on the principles of Sharia , and be able to compete and be as popular as conventional banks, so that it will have a positive 
impact on their business performance. Considering the important role of the job performance, the literature shows an important role in employee religiosity toward job performance (OsmanGani, Hashim, \& Ismail, 2013).

Meanwhile, from the consumer's context, religiosity is also seen as a factor affecting the customers of Islamic bank (Nizar \& Marzouki, 2015; Wahyuni, 2017; Suhartanto 2018). Although many researches have highlighted the importance of religiosity on someone attitudes and behaviors, there have not been researches that examine the effect of religiosity on the job performnace of Islamic banks. Thus, it is still a big question on how religiosity can affect the job performance of Islamic banks. Analysis of the issue of religiosity in Islamic Bank is important considering the basic principles of the banks that are based on Sharia values. The research on the effect of religiosity on job performance allows the managers of Islamic banks to develop the potential of the employees in the term of religiosity, so that the performance of the company becomes better.

Based on the existing problems, this research then discusses the effect of religiosity on the job performance of Islamic banks. This research is specifically to (1) examine the direct effect of religiosity on the job performance and (2) to examine the indirect effect of religiosity on the job performance through the employee engagement and the job satisfaction. This research, in the context of Sharia banking, especially the West Java Sharia Rural Bank, was conducted for three reasons. First, the growth of Sharia banking tends to stagnate within small assets; $5 \%$ of national banking assets (BI, 2017). Second, the growth of the number of Sharia Rural Bank employees has a significant increase; in 2014 there were 4,704 employees and in 2015 there were 5,102 employees (OJK, 2017). Third, the asset amount of Sharia Rural Bank in West Java is the highest compared to other provinces, which reaches 3,001,429 (in million IDR) (OJK, 2017). Thus, knowing the effect of Sharia bank employees' religiosity is very important for the development of human resources in Islamic Banks in Indonesia.

\section{LITERATURE REVIEW AND RESEARCH HYPOYHESES}

\section{Religiosity}

Religiosity and religion are often used interchangeably to interpret the same concept; respect, dedication and individual belief in divinity (Nizar \& Marzouki, 2015). According to Stark and Glock (1970), religion is as a symbol system, belief system, value system and institutionalized behavioral system centered on something that is perceived as something meaningful. Whereas according to Mathras (2016), religion is a gift to its followers, a series of certain beliefs, rituals, values and communities. Similar to the previous opinion, Shyan Fam (2004) argues that religion is an ideal for life, which is reflected in the values and attitudes of each of its followers. However, religiosity, which comes from religious words, has different meaning. Mansour (2016) explains that religiosity shows the level of someone's adherence to religious beliefs and the practices reflected in daily life. Similar to what has been explained previously, McDaniel (1990) defines religiosity as a faith in Allah and the loyalty of His followers in obeying the rules set by Him. Mathras (2016) explains that religiosity is a personal commitment to obey divined rules that can affect social life and also affect individuals in determining the attitude. 
Sedgwick (2006) argues that differences in the level of religiosity in Islam can be seen clearly. Some Muslims obey the religion they adhere to, while others do it less. In these two levels of compliance, there are similarities held by Muslims; monotheism (belief in Allah SWT) and the prophet hood (to the Prophet Muhammad). In addition, according to Porter (2008) Al-Qur'an is interpreted, understood and reflected in everyday life differently, thus it affects the diversity of the level of individual religiosity. The study from Abou-Youssef, Kortam, Abou-Aish, and ElBassiouny (2015) explains that the level of religiosity can be measured in several ways, it can be seen at how often the person is worshiping. Devout Muslims pray five times in a predetermined time, and obey the Sharia and the Sunnah. Further measurements can be seen from the Muslim, how often they do the Friday prayers and do not leave them. Furthermore, the final measurement can be seen from whether they carry out fasting in Ramadan. Meanwhile, Krauss (2007) assumes that the level of religiosity in Islam can be seen through two things, the view of the world and the faith that is in accordance with the Qur'an and the Sunnah.

Some researches show that the religiosity determines someone's attitude. Nizar and Marzouki (2015) explain that someone's beliefs tend to be strongly related to their religion, either directly or through scripture or indirectly through individual culture. In accordance with the statement, someone's religious identity will influence behavior and attitude (Tang, 2015). Several studies on the effect of religiosity in Sharia banks have been carried out such as by Nizar and Marzouki (2015) and the research on the effect of religiosity on the job performance by (Osman-Gani et al., 2013). Besides, religiosity can also affect the job satisfaction of the employees (King, 2005).

\section{Job Performance}

Job performance is the behavior of individuals or the employees who contribute to the technical organization (Bertolino, 2013). Performance is the most basic thing in assessing the effectiveness of individuals who contribute to an organization ( $\mathrm{Ng}, 2009)$. Job performance, according to Borman (1993), consists of three components: assignments, additional tasks to customers and additional tasks for the organization or company. The assignments in the task refer to the main task of the employee. Additional tasks for customers are the employee discretion that indirectly influences the service to the customers. The additional tasks for the organization refer to the employee's desire to advance the organization.

According to Chu and Lai (2011), performance is incidental, measurable and diverse behavior that can be measured by the standards of an organization. According to Tseng and Huang (2011), job performance can be measured in several ways; quality of work, timeliness, performance, productivity, effectiveness of training, assessment, work results, behavior and individual characteristics. Job performance is influenced by two aspects; (1) the personal quality of the individual which includes knowledge, skills, capacity, and motives and (2) the aspect of the work environment that describes work expectations, awards, workspace, equipment and incentives.

To make the job performance optimal, the companies must be able to motivate and satisfy the employees so that they can work optimally (Bowen, 2004). Another opinion states that the employee performance has three factors; individual, organization and work climate (Liao, 2004). Individual factors are the personality of the employees starting from neuroticism, extroversion and generosity. The organizational factors are the employee engagement, training and incentives. Work climate factors refer to the views among the employees regarding procedures, policies and practices. Based on the discussion, the hypothesis that can be formulated regarding the employee and the bank performance is as follows. 
$\mathrm{H}_{1}$ : Religiosity has a positive effect on the job performance

\section{The Role of Employee Engagement}

Employee engagement is the engagement of individuals in an organization by 'utilizing the members of the organization' as the responsibility of their job (Kahn, 1990). Based on this opinion, the bound employees tend to devote themselves to their job physically and emotionally, but are inversely proportional to the employees who break away from their responsibilities in the organization; they are more selfish towards their job. According to Bakker, Schaufeli, Leiter, and Taris (2008), the employee engagement is based on two factors, job demand resources capital and psychological capital. The job demand capital includes the environment, social and physical relation, salary, opportunity to support, support from superiors and support from colleagues. The psychological capital includes the confidence, optimism, happiness and hope about the future. The higher positive impact of engagement an employee has the lower tendency of the employee to leave the job.

According to Haruna (2017), the employee engagement shows how an employee trusts and enjoys what he does and values the relation to his profession. Based on this, it implies that the employee engagement describes the positive thoughts of the employees towards their job, while the employees who are not engaged will be cut off from their job. In line with this, the employees who engage to their job will care about their work emotionally and physically (Shuck, 2011).

Based on Social Exchange Theory Cropanzano (2005), the relationship between the employees and the organization is a two-way relationship. This theory explains that the employee engagement with the organization is a relationship that is interdependent toward each other. Based on this theory, the relationship between the parties will give the positive things such as trust, loyalty and commitment if they convince the rules that exist between them. The rules of exchange between them usually contain a joint rule that the action of one party will cause the other one to respond, as happens between the employees and their organizations (Teller, 2016). As an illustration, when an employee of Sharia bank gets rewards from the bank he works for, he feels grateful to give a respond in the form of positive interactions with the colleagues and the customers, so that it will have a positive impact on his performance as well as the bank's. In short, the employee engagement reflects the benefits they get from the organization.

Fredrickson (2001) in the broaden-and-build theory explains that the positive emotions such as happiness, attention and satisfaction will expand the thinking and develop someone's personal potential. Therefore, it will create broad reasoning and improve someone ability in various ways (Saks, 2006). Research from Yeh (2013) in the field of tourism shows that the employees who are satisfied with their job will have the high job performance.

In the previous literature, Shuck (2011) describes that the employees who work better generally feel engaged, more cared for, more fulfilled and more productive than those who do not. The research of Suhartanto, Dean, Nansuri, and Triyuni (2018) which examines the employee engagement in tourism reports that the employees who have high engagement in tourism tend to have high service performance as well. In addition to these researches, there are other researches that show a positive effect of the employee engagement toward effective commitment, job satisfaction and performance (Soane et al., 2012; Yalabik, Popaitoon, Chowne, \& Rayton, 2013). This discussion shows that the employee engagement directly affects the job performance and it is the connecting factor between religiosity and the job performance. Another research conducted by Slatten (2011) in the field of tourism also shows that the employee engagement mediates the relationship between value alignment, organizational support and organizational 
performance. This discussion implies that the employees who are engaged in their job will do their jobs better. So that the relationship between the religiosity, the employee engagement and the performance is as follows.

$\mathrm{H}_{2}$ : Religiosity has a positive effect on the employee engagement

$\mathrm{H}_{3}$ : Employee engagement has a positive effect on job performance

\section{The Role of Job Satisfaction}

Job satisfaction is a pleasant emotional condition, a consequence of the achievement of the given working standard (Locke, 1969). Based on this definition, the job satisfaction in individuals tends to be temporary, not related to the future, but at the present time and the past. Meanwhile, according to Lambert, Hogan and Griffin (2007), job satisfaction can be defined as the employee's reaction to his job and whether the employee enjoys the work he does. Another opinion describes job satisfaction as a positive emotion that increases from the employee's assessment of the work he has done (Hair, Black, Babin, Anderson, \& Tatham, 1998).

Several studies have discussed a lot about the job satisfaction. One of them is Saks (2006) who explains that one of the important factors that drives the job satisfaction is the employee engagement and organization. The employees who are engaged to their job tend to show their favorable behavior towards their job. Other research shows that job satisfaction is a driver in achieving the goals of an organization (Lu, 2016). In addition, the other study conducted by Gursoy (2007) says that job satisfaction affects the organizational goals because it provides gifts and a comfortable environment both physically and mentally. Based on some opinions and researches, the employees who are satisfied with their job tend to provide better performance than those who are not.

The spillover theory of Sirgy (2011) explains that someone's satisfaction in one part of his life can affect satisfaction in other parts. For example, when an employee feels satisfied with the job he receives, it can affect the satisfaction in other aspects of his life, such as his performance and his family. The literature from Koys (2003) reveals that job satisfaction is the main factor to achieve organizational goals. Another opinion from Gursoy (2007) states that the organization that creates a sense of comfort can provide the satisfaction to its employees so that it helps the organization achieves its goals. The employees who feel satisfied will work better. They will also be encouraged to work harder than the unsatisfied one. The satisfied employees tend to work more professionally and provide the best performance so that it will also result better company performance (Koys, 2003). This discussion implies that an employee with high religiosity will be satisfied with his job and then work better. Based on this, the hypotheses can be formulated as follows.

$\mathrm{H}_{4}$ : Religiosity has a positive effect on job satisfaction

$\mathrm{H}_{5}$ : Job satisfaction has a positive effect on job performance

$\mathrm{H}_{6}$ : Employee engagement has a positive effect on job satisfaction

$\mathrm{H}_{7}$ : Religiosity has a direct effect on job performance through employee engagement and job satisfaction 


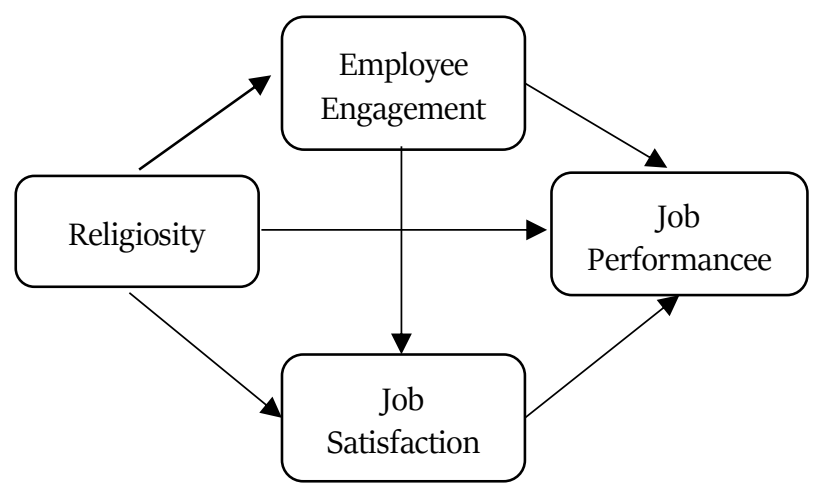

Figure 1. The proposed model

\section{RESEARCH METHOD}

This research focuses on the religiosity of the employees of Sharia Rural Bank, so that the variables of religiosity used were in the context of Islam. The scale of religiosity used was based on (Stark \& Glock, 1970). The application of the scale of religiosity was based on Islamic and psychometric values that are reliable and valid. The experts claim that the self-reported measurement is an accurate method of capturing perceptual data, such as employee engagement, job satisfaction and job performance (Netemeyer \& Maxham III, 2007). Based on this opinion, this research used questionnaire items, based on the literature obtained. The employee engagement was measured by several indicators that reflect pleasure, risk probability, adopted and adapted based on previous research (Suhartanto \& Brien, 2018). The job satisfaction was measured by four indicators adopted from (Chi \& Gursoy, 2009). The job performance was measured by seven indicators adapted from previous research (Chi \& Gursoy, 2009). All indicators in this research are Likert scale variables. The score from the Likert scale was measured by 5 points ( 1 strongly disagrees to 5 strongly agree).

This research viewed the influence of religiosity that was tested on the employees of Sharia Rural Bank in West Java. The sampling method used was simple random sampling. The data were collected during November 2017 - March 2018. Of the 350 questionnaires distributed, 250 were returned and used for analysis. According to Hidayat, Akhmad, and Machmud (2015) the guidelines for the sample size in the study are around 100-200 samples.

This research examined the construct validity and reliability by applying variance-based Structural Equation Modeling (SEM-PLS). This method was used to verify the model that had been proposed. In addition, SEM-PLS techniques allows researchers to assess the latent constructs using small and medium distributed data and non-normality (Chin, Peterson, \& Brown, 2008; Dean \& Suhartanto, 2019). Based on the opinion of Hair Jr, Hult, Ringle, and Sarstedt (2016) SEMPLS is a technique that is recognized to estimate the coefficient track in a structural model. 


\section{RESULTS}

Table 1 summarizes the respondent's description of the data collected and shows the characteristics of respondents.

Table 1. Characteristic of the respondent

\begin{tabular}{llll}
\hline Variable & Description & Frequency & $\%$ \\
\hline \multirow{2}{*}{ Gender } & Man & 147 & 58,8 \\
& Woman & 103 & 41,2 \\
& $<25$ & 56 & 22,4 \\
Age & $25-35$ & 146 & 58,4 \\
& $36-45$ & 36 & 14,4 \\
& $>45$ & 12 & 4,8 \\
\multirow{2}{*}{ Education } & High School & 2 & 0,8 \\
Level & Bachelor/Diploma & 26 & 10,4 \\
& Postgraduate & 5 & 86,8 \\
& & & 2 \\
\hline
\end{tabular}

\section{Measurement Model}

In the testing phase of the proposed model, this research used two stages of testing. The first stage was testing the measurement model with Average Variance Extracted (AVE), Outer Weights and Composite Reliability to test the discriminant and convergent validity and construct reliability. The convergent validity tests reveal that the prerequisites for validity are met if AVE is higher than 0.5, the composite reliability is more than 0,7 and exceed load factor exceeds o.6 (Hair et al., 1998). Based on this, it can be seen in the table 2 that all factors loading values in this research have values of more than 0.6 , Cronbach alpha rho and composite reliability have values above 0.7, and the value of Average Variance Extracted (AVE) has value above 0.5. Based on this result it can be concluded that all indicators in this research are valid and have good reliability. In addition, based on Henseler, Ringle, and Sarstedt (2015), there are other ways to get the convergent validity values based on the Heterotrait-Monotrait ratio of correlations (HTMT). It states that the HTMT value of distribution is smaller than 0.85 and the confidence interval value is smaller than 1.o. It can be stated that it has the discriminant validity (Abugabah, 2010).

\section{Structural Model}

Based on Hair Jr et al. (2016), a bootstrapping method with 500 repeated petitions was applied to assess the significance of the indicator weight and path coefficient. In addition, R2 was corrected from all estimated constructs using diagnostic tools to evaluate the right model. The measurement of the Goodness of Fit (GoF) applied the geometric mean of the communality and the average R2 for the endogenous construct. The standards for evaluating the results of GoF analysis are small (0.02), medium (0.25) and large (o.36) (Hair Jr et al., 2016). In this research, the GoF value is 0.418 (see Table 4). It shows that the proposed relationship model between the effect of religiosity on the performance, job satisfaction and employee engagement on the Sharia banks performance has a large value and indicates that the model runs relatively well. 
Table 2. The loading, Cronbach's alpha, composite reliability (CR), and AVE

\begin{tabular}{|c|c|c|c|c|}
\hline Construct/item & Loading & $\begin{array}{c}\text { Cronbach } \\
\alpha \\
\end{array}$ & CR & AVE \\
\hline Employee Engagement & & 0,858 & 0,897 & 0,598 \\
\hline When I work, I fully concentrate on the job & 0,564 & & & \\
\hline It captivates my heart to become an employee at Sharia banks & 0,833 & & & \\
\hline I understand what happens at my bank & 0,650 & & & \\
\hline Becoming an employee at Sharia banks makes me excited & 0,866 & & & \\
\hline I am so happy to be an employee of this Sharia bank & 0,837 & & & \\
\hline I feel very engaged with this Sharia bank & 0,837 & & & \\
\hline Job Performance & & 0,772 & 0,845 & 0,523 \\
\hline I always achieve the target set by the company & 0,730 & & & \\
\hline I often get awards for my performance & 0,689 & & & \\
\hline I am always on time in doing my job & 0,759 & & & \\
\hline I always follow the rules of the company & 0,684 & & & \\
\hline Overall, I work very well & 0,749 & & & \\
\hline Job Satisfaction & & 0,795 & 0,880 & 0,710 \\
\hline Overall, I am satisfied with my job & 0,798 & & & \\
\hline In the future, I want to keep working in Sharia banking & 0,865 & & & \\
\hline I have never thought of quitting my current job & 0,863 & & & \\
\hline Religiosity & & 0,894 & 0,913 & 0,513 \\
\hline I like reading books about religion & 0,642 & & & \\
\hline I like to follow Islamic studies on TV & 0,588 & & & \\
\hline I always help friends who are in trouble & 0,728 & & & \\
\hline I set aside money for charity & 0,780 & & & \\
\hline I forgive people who hurt me & 0,709 & & & \\
\hline I always try to be honest people & 0,729 & & & \\
\hline I feel disappointed when I miss the pray & 0,774 & & & \\
\hline When I pray regularly, I feel peaceful & 0,748 & & & \\
\hline I believe God see everything I do & 0,740 & & & \\
\hline God will grant my prayer, if I mean it & 0,700 & & & \\
\hline
\end{tabular}

** Significant at $p<0.01$

Table 3. Heterotrait Monotrait Ratio (HTMT)

\begin{tabular}{lllll}
\hline & $\begin{array}{l}\text { Employee } \\
\text { engagement }\end{array}$ & Job performance & $\begin{array}{l}\text { Job } \\
\text { satisfaction }\end{array}$ & Religiosity \\
\hline Employee engagement & & & & \\
Job performance & 0,630 & & & \\
Job satisfaction & 0,710 & 0,705 & \\
Religiosity & 0,576 & 0,471 & 0,498 & \\
\hline
\end{tabular}

Table 4. Goodness of Fit (GoF) index

\begin{tabular}{lll}
\hline Variable & $\mathrm{AVE}$ & $\mathrm{R}^{2}$ \\
\hline Job performance & 0.523 & 0.379 \\
Job satisfaction & 0.710 & 0.378 \\
Employee engagement & 0.598 & 0.261 \\
Religiosity & 0.513 & \\
Average score & 0.586 & 0.339333 \\
AVE $\times \mathrm{R}^{2}$ & & 0.198849 \\
GoF $=\sqrt{ }\left(\mathrm{AVE}_{\mathrm{R}} \mathrm{R}^{2}\right)$ & & 0.445925 \\
\hline
\end{tabular}


Table 5. Path Coefficient

\begin{tabular}{lllllll}
\hline \multicolumn{1}{c}{ Path } & \multicolumn{2}{c}{$\begin{array}{c}\text { Direct Effect } \\
\text { t-value }\end{array}$} & $\begin{array}{r}\text { Indirect Effect } \\
\text { t-value }\end{array}$ & \multicolumn{2}{c}{$\begin{array}{c}\text { Total Effect } \\
\text { t-value }\end{array}$} \\
\hline Religiosity $\rightarrow$ Job performance & 0.133 & $2.497^{*}$ & 0.278 & $6.319^{* *}$ & 0.411 & $8.408^{* *}$ \\
Religiosity $\rightarrow$ Employee engagement & 0.511 & $10.624^{* *}$ & & & 0.511 & $10 ., 624^{* *}$ \\
Religiosity $\rightarrow$ Job satisfaction & 0.179 & $2.664^{* *}$ & & & 0.179 & $2.664^{* *}$ \\
Employee engagement $\rightarrow$ Job performance & 0.236 & $3.214^{* *}$ & & & 0.236 & $3.214^{* *}$ \\
Job satisfaction $\rightarrow$ Job performance & 0.360 & $4.865^{* *}$ & & & 0.360 & $4.865^{* *}$ \\
Employee engagement $\rightarrow$ Job Satisfaction & 0.504 & $8.783^{* *}$ & & & 0.504 & $8.783^{* *}$ \\
\hline
\end{tabular}

* Significant at $p<0.05 ;{ }^{* *}$ Significant at $p<0.01$

Table 5 shows that religiosity positively and significantly affects the job performance of Islamic banks, both directly and indirectly. The religiosity directly affects the job performance which has a coefficient value of (o.179). Based on this result, $\mathrm{H}_{1}$ is accepted. The employee engagement is a connecting factor between the religiosity and the job performance and has a positive and significant value with coefficient value of (o.418). Based on this result, $\mathrm{H} 2$ is accepted. The employee engagement has a positive and significant influence on the employee job satisfaction with a coefficient value of (0.504). Based on this result, then $\mathrm{H}_{3}$ is accepted. The employee job satisfaction is also a connecting factor between religiosity and job performance with a positive and significant value with a coefficient of 0.360. Based on the results of the Smart PLS analysis, it can be seen that all constructs in this research have significant values, and all hypotheses can be accepted.

\section{DISCUSSION}

The previous research has examined the effect of religiosity on job performance (King, 2005; Osman-Gani et al., 2013). In addition, the research about the effect of religiosity on Sharia bank customers has also been carried out (Nizar \& Marzouki, 2015; Suhartanto 2018). However, from several researches there is none that explains the effect of religiosity on the job performance of Sharia banks. The results of this research provide a plausible explanation for the effect of religiosity on the performance of Sharia banks through the employee engagement, the job satisfaction and the job performance.

First, this research reveals that religiosity influences positively and significantly, as well as directly and indirectly on job performance. It shows the effect of religiosity directly has a coefficient of (0.133) and indirectly (0.278). This result indicates that religiosity will affect the job performance more significantly if the employee engagement and the job satisfaction have been achieved. This finding shows that someone with a high level of religiosity will work so well. Thus, it shows that the employees do not just see working as worshiping. In other words, the indirect effect of religiosity on the job performance shows that the employees of Sharia banks also look for blessings in work, besides seeking satisfaction in order to fulfill their needs. It is because the employee satisfaction is influenced by some factors; reward, facilities and career in the future (Gursoy, 2007). This result also confirms the statement from Cropanzano (2005); Teller (2016) that the individuals and the organizations need each other, if one acts then the other will respond. In other words, if the employee is satisfied with his job, he will provide his optimal performance and organizational goals will be achieved for sure. 
Second, this research shows that employee engagement is a connecting factor between religiosity and job performance with positive and significant value. This finding shows that someone with a high level of religiosity will have a high ethical level, so that he will be responsible and engaged on his job (Beit-Hallahmi., 1997). Thus, these findings indicate that the employees of Sharia banks who have a high level of religiosity realize that working is not only paying responsibility to superiors but also to God Allah SWT, so the employees will be very engaged on their job. The positive effects of the good employee engagement will have an effective commitment, job satisfaction and performance (Soane et al., 2012). This also strengthens the revelation from Bakker et al. (2008) who states that the employee engagement is influenced by psychological aspects. In addition, this also reinforces that employees with their high employee engagement will make them work better. It strengthens the previous research from Itam (2017) who reports that the employees who are engaged with their job will show a positive attitude, satisfaction in the job and job performance. Similar to the research of Suhartanto and Brien (2018) which reports that the retail employees who are engaged with their job will have a positive effect on their performance. Some previous literatures and researches that have been conducted indicate that the higher someone religiosity will result on the higher care and engagement they give to his organization or his job. This is because, the more someone understands the religion, the more he realizes that everything he does must be accounted, and it includes to the job he is engaged in.

Third, this research shows that the employee engagement influences positively and significantly on the job satisfaction. It explains that the employees who are fully engaged in their job will satisfy and appreciate their performance. It is consistent with the theory of Fredrickson (2001) in the broaden-and-build theory which explains that the positive emotions such as happiness, attention and satisfaction will expand the thinking and develop someone's personal potential. Therefore, the positive emotions will create the large reasoning and improve someone's ability in various ways (Saks, 2006). This is also in accordance with Yeh (2013) research in the field of tourism which shows that the satisfied employees with their job have the high employee engagement.

Fourth, this research reveals that religiosity of the employee impacts directly on his job satisfaction, while indirectly on his job performance. These findings show that if it is on the high level religiosity, an employee will be more responsible and bound to his job and if it is good, he tends to be more grateful and satisfied. If the employees are engaged and satisfied on their job, their performance will be better and the company performance will be better too. Conversely, the employees with a low level of religiosity will tend to be less engaged on their job and less satisfied which ultimately haves a poor performance and give a negative impact for the bank. This finding strengthens the statement from $\mathrm{Lu}$ (2016); Saks (2006) which state that the employees who are engaged and satisfied on their work will facilitate the organization in achieving its goals. Besides, this finding also strengthens the previous research of Abou-Youssef et al. (2015) which explains that the high religiosity will affect someone to act more ethically. In other words, the employees who have high religiosity will be more attached to their job and feel satisfied with their performance. 


\section{THEORETICAL AND PRACTICAL IMPLICATION}

This research extends our knowledge about the influence of the employee religiosity in Sharia banks with employee engagement, job satisfaction and job performance. Testing the proposed religiosity model provides support and extends the supporting theories and research hypotheses in the future. This research provides support to Osman-Gani et al. (2013) which explains the employee religiosity. This support reinforces that the spirituality and the religiosity will affect the job performance. This research also shows that religiosity is an important factor that determines the performance of the job. It reinforces the statement of Shyan Fam (2004) that the religion reflects the values and the attitudes of the followers. Religiosity affects someone not only in his social communication, but also in making decisions (Mathras, 2016). In addition, according to what is conveyed by Essoo (2004) that the level of religiosity is associated with the job performance, the religion influences an employee in his behavior and attitudes. Thus, it can be concluded that religion is the important determinants in shaping the performance of an employee.

\section{MANAGERIAL IMPLICATION}

This research has significant practical implications for Sharia bank managers. The findings in this research have a number of implications in managing the Sharia banks. First, this research reveals that the employees with high levels of religiosity tend to have a good employee engagement and a job satisfaction, thus affecting their performance. Thus, besides looking for the employees based on the ability in accordance with their fields, the managers of Sharia bank also need to assess their level of religiosity so that operations can be in accordance with the concept of Sharia. Sharia banks can improve its performance even better in accordance with the findings above which state that religiosity has a positive influence on the job performance in order to work with standards that apply to Sharia banks. Second, for the existing of the Sharia bank employees, the managers and the company leaders can improve the religiosity by holding various kinds of religious activities such as routine recitation, training or giving award such as umrah or hajj for the outstanding employees. It increases the job satisfaction and provides a sense of comfort for the employees as well as prevents them to look for other job in other companies. It will make the bank focuses on its operational activities and so that the bank can improve services to its customers.

\section{LIMITATION AND FUTURE RESEARCH}

The first limitation of this research relates to the data collection and the use of single administration cross-sectional design. It is limited to its ability to capture the dynamic relationship between the constructs of attitudes and imaginary construction (job performance and Sharia banks performance). Thus, if the construction tends to change over time, the interpretation of the findings of this research is limited. To overcome this limitation, the future research can use the old designs, and compare the results for the changes. The second limitation of this research is related to the questionnaire distribution. Many questionnaires that had been distributed were not returned. The selected sample is only the Sharia Rural Bank. For further research the selected 
sample can be from Sharia Commercial Banks, Sharia Business Units and Sharia Rural Bank, so that the samples are easier to collect.

\section{REFERENCES}

Abou-Youssef, M. M. H., Kortam, W., Abou-Aish, E., \& El-Bassiouny, N. (2015). Effects of religiosity on consumer attitudes toward Islamic banking in Egypt. International Journal of Bank Marketing, 33(6), 786-807. doi: 10.1108/IJBM-02-2015-0024

Abugabah, A., \& Sanzogni, L. (2010). Enterprise resource planning (ERP) system in higher education: A literature review and implications. International Journal of Human and Social Sciences, 5(6), 395-399. doi: 10.5281/zenodo.1060431

Bakker, A. B., Schaufeli, W. B., Leiter, M. P., \& Taris, T. W. (2008). Work engagement: An emerging concept in occupational health psychology. Work \& Stress, 22(3), 187-200. doi: $10.1080 / 02678370802393649$

Beit-Hallahmi., A., M. (1997). The Psycholgy of Religious Behavior, Belief and Experience.

Bertolino, M., Truxillo, d., \& Fraccarolii. (2013). Age Effect on Perceived Personality and Job Performance. Journal of managerial Psychology, 28, 867-885. doi: 10.1108/JMP-07-2013-0222

BI. (2017). Laporan Tahunan Bank Indonesia.

Borman, W. C., \& Motowidlo, S. J;. (1993). Expanding the criterion domain to include elemnts of contextual performance. In N. Schmitt \& W. C. Borman (eds.). Personal Selection in Organizations, 71-98.

Bowen, J., \& Ford, R. C. . (2004). What experts say about managing hospitality service delivery systems. International Journal of Contemporary Hospitality Management, 16(7), 394-401. doi: 10.1108/09596110410559078

Chi, C. G., \& Gursoy, D. (2009). Employee satisfaction, customer satisfaction, and financial performance: An empirical examination. International Journal of Hospitality Management, 28(2), 245-253. doi: 10.1016/j.ijhm.2008.08.003

- Chin, W. W., Peterson, R. A., \& Brown, S. P. (2008). Structural equation modeling in marketing: Some practical reminders. Journal of marketing theory and practice, 16(4), 287298. doi: 10.2753/MTP1069-6679160402

Cropanzano, R. a. M., M.S. . (2005). Social Exchange Theory : An Interdisciplinary Review. Journal of Management, 31 No.6, 874-900. doi: 10.1177/0149206305279602

Dean, D., \& Suhartanto, D. (2019). The formation of visitor behavioral intention to creative tourism: the role of push-Pull motivation. Asia Pacific Journal of Tourism Research, 1-11. doi: 10.1080/10941665.2019.1572631

Essoo, N., \& Dibb, S. (2004). Religious Influences on Shopping Behaviour : An Exploratory Study. Journal of Marketing Management, 2o(7-8), 683-712. doi: 10.1362/D267257041838728

Fredrickson, B. L. (2001). The role of positive emotions in positive psychology : The broade-andbuild theory of positive emotions. American Psychologist, 56, 218-226.

Gursoy, D., \& Swanger, N. (2007). Performance-enhancing internal strategic factors : impact on financial success. international Journal of Hospitality management, 26(1), 213-227. doi:10.106/j.ijhm.2006.01.004

Hair, J. F., Black, W. C., Babin, B. J., Anderson, R. E., \& Tatham, R. L. (1998). Multivariate data analysis . Uppersaddle River. Multivariate Data Analysis (5th ed) Upper Saddle River.

Hair Jr, J. F., Hult, G. T. M., Ringle, C., \& Sarstedt, M. (2016). A primer on partial least squares structural equation modeling (PLS-SEM): Sage Publications. 
Haruna, A. y., \& marthandan, G. (2017). Foundational competencies for enhancing work engagement in SMEs Malaysia. Journal of Workplace Learning, 29(3), 165-184. doi: 10.1108/JWL-07-2016-0066

Hassan Fathelrahman Mansour, I., \& Mohammed Elzubier Diab, D. (2016). The relationship between celebrities' credibility and advertising effectiveness. Journal of Islamic Marketing, 7(2), 148-166. doi:10.1108/JIMA-05-2013-0036

Henseler, J., Ringle, C. M., \& Sarstedt, M. (2015). A new criterion for assessing discriminant validity in variance-based structural equation modeling. Journal of the academy of marketing science, 43(1), 115-135. doi: 10.1007/s11747-014-0403-8

Hidayat, R., Akhmad, S., \& Machmud, M. (2015). Effects of Service Quality, Customer Trust and Customer Religious Commitment on Customers Satisfaction and Loyalty of Islamic Banks in East Java. Al-Iqtishad: Jurnal Ilmu Ekonomi Syariah, „(2), 151-164.

Itam, U. S. S. (2017). Examining the Mediation Effect of Employee Engagement on Internal Brand Practices and Outcome Variable in the Organized Retail Sector. International Business Management, 11(3), 673-682. doi: 10.36478/ibm.2017.673.682

Kahn, W. A. (1990). Psychological conditions of personal engagement and disengagement at work. Academy of management journal, 33(4), 692-724. doi: 10.5465/256287

King, J. E., \& Williamson, I. O. (2005). Workplace religious expression, religiosity and job satisfaction : Clarifying a relationship. Journal of Management, Spirituality \& Religion, 2(2), 173-198. doi: 10.1080/14766080509518579

Koys, D. (2003). How the achievement of human-resources goals drives restaurant performance. Cornell Hotel and Restaurant Administration Quarterly, 44(1), 17-24. doi: 10.1016/Soo108804(03)90042-5

Krauss, S. E., Hamzah, A., \& Idris, F. (2007). Adaptation of a Muslim Religiosity Scale for Use with Four Different Faith Communities in Malaysia. Review of religious research, 49(2), 147-164.

Lambert, E. G., Hogan, N. L., \& Griffin, M. L. (2007). The impact of distributive and procedural justice on correctional staff job stress, job satisfaction, and organizational commitment. Journal of Criminal Justice, 35(6), 644-656. doi:10.1016/j.jcrimjus.2007.09.001

Liao, H., \& Chuang, A. (2004). A multilevel investigation of factors influencing employee service performance and customer outcomes. Academy of Management Journal, 47(1), 41-58. doi:10.2307/20159559

Locke, E. A. (1969). What is job satisfaction? Organizational behavior and human performance, 4(4), 309-336.

Lu, L., Lu, A.C. C., Gursoy, D., \& Neale, N. R. (2016). Work Engagement, Job Satisfaction, and turnover intentions. International Journal of Contemporary Hospitality Management, 28(4), 737-761. doi:10.1108/ijchm-07-2014-036o

Mathras, D., Cohen, A. B., Mandel, N., \& Mick, D. G. (2016). The effects of religion on consumer behavior: A conceptual framework and research agenda. Journal of Consumer Psychology, 26(2), 298-311. doi:10.1016/j.jcps.2015.08.001

McDaniel, S. W., \& Burnett, J. J. . (1990). Consumer religiosity and retail store evaluative criteria. Journal of the Academy of Marketing Science, 18(2), 101-112. doi: 10.1007/BFo2726426

Muslim, A., Zaidi, I., \& Rodrigue, F. (2013). Islamic banks: Contrasting the drivers of customer satisfaction on image, trust, and loyalty of Muslim and non-Muslim customers in Malaysia. International Journal of Bank Marketing, 31(2), 79-97. doi:10.1108/02652321311298627

Netemeyer, R. G., \& Maxham III, J. G. (2007). Employee versus supervisor ratings of performance in the retail customer service sector: Differences in predictive validity for customer outcomes. Journal of Retailing, 83(1), 131-145. doi: 10.1016/j.jretai.2006.10.009 
Ng, T. W., Sorensen K.L \& Yim, F.H. (2009). Does The Job Satisfaction-Job Performance Relationship Vary Across Cultures. Journal of Cross-Cultural Psychology, 4o(5), 761-796. doi: 10.1177/0022022109339208

Nizar, S., \& Marzouki, R. (2015). Consumer attitudes and purchase intentions toward Islamic banks: the influence of religiosity. International Journal of Bank Marketing, 33(2), 143-161. doi: doi:10.1108/IJBM-10-2013-0115

OJK. (2017). Statistik Perbankan Syariah.

Osman-Gani, A. M., Hashim, J., \& Ismail, Y. (2013). Establishing linkages between religiosity and spirituality on employee performance. Employee relations, 35(4), 36o-376. doi: 10.1108/ER04-2012-0030

Porter, M. E., \& Schwab, K. (2008). The Global Competitveness Report 2008-2009. World Economic Forum.

Saks, A. M. (2006). Antecedents and consequences of employee engagement. Journal of Managerial Psychology, 21(7), 6oo-619. doi: 10.1108/02683940610690169

Saleh, M. A., Quazi, A., Keating, B., \& Gaur, S. S. (2017). Quality and image of banking services: a comparative study of conventional and Islamic banks. International Journal of Bank Marketing, 35(6), 878-902. doi: 10.1108/IJBM-08-2016-0111

Sedgwick, M. J. (2006). Islam \& Muslims : a guide to diverse experience in a modern world. Boston, MA: Intercultural Press. .

Shuck, B. (2011). Four Emeerging Perspectives of Employee Engagement : An integrative Literature Review. Human Resource Development Review, 10(3), 304-328. doi:10.1177/1534484311410840

Shyan Fam, K., Waller, D. S., \& Zafer Erdogan, B. (2004). The influence of religion on attitudes towards the advertising of controversial products. European Journal of Marketing, $38(5 / 6)$, 537-555. doi:10.1108/03090560410529204

Sirgy, M. J., Kruger, P. S., Lee, D. J., \& Yu, G. B. (2011). How does a travel trip affect torist' life satisfaction? Journal of Travel Research, 5o(3), 261-275. doi: 10.1177/0047287510362784

Slatten, T., \& Mehmetoglu, M. (2011). Antecedents and effects of engaged frontline employees. Managing Service Quality : An International Journal, 21(1), 88-107. doi: 10.1108/09604521111100261

Soane, E., Truss, C., Alfes, K., Shantz, A., Rees, C., \& Gatenby, M. (2012). Development and application of a new measure of employee engagement: the ISA Engagement Scale. Human Resource Development International, 15(5), 529-547. doi: 10.1080/13678868.2012.726542

Sri Wahyuni., N. F. (2017). Brand Religiosity Aura and Brand Loyalty in Indonesia Islamic Banking. Journal of Islamic Marketing, 1-16. doi: 10.1108/JIMA-o6-2015-0044

Stark, R., \& Glock, C. Y. (1970). American piety: The nature of religious commitment (Vol. 1): Univ of California Press.

Suhartanto, D. and Brien, A. (2018), "Multidimensional engagement and store performance", International Journal of Productivity and Performance Management, Vol. 67 No. 5, pp. 8o9-824. doi: 10.1108/IJPPM-03-2017-0065

Suhartanto, D., Dean, D., Nansuri, R., \& Triyuni, N. (2018). The link between tourism involvement and service performance: Evidence from frontline retail employees. Journal of Business Research, 83, 130-137. doi: 10.1016/j.jbusres.2017.10.039

Suhartanto , F. N., H., Muflih,M ., \& Setiawan. (2018). Loyalty Intention towards Islamic Bank : The Role Of Religiosity, Image, and Trust. International Journal of Economics and Management, 12, 137-151. 
Tang, G., \& Li, D. (2015). Is there a relation between religiousity and customer loyalty in the Chinese context? International Journal of Consumer Studies, 39(6), 639-647. doi : 10.1111/ijcs.12197

Teller, C., Alexander, A \& Floh, A. (2016). The Impact of Competition and Cooperation on the Performance of a Retail Agglomeration and its Stores. Industrial Marketing Management, 52, 6-17. doi: 10.1016/j.indmarman.2015.07.010

Tseng, S.-M., \& Huang, J.-S. (2011). The correlation between Wikipedia and knowledge sharing on job performance. Expert systems with applications, 38(5), 6118-6124. doi: 10.1016/j.eswa.2010.11.0o9

Yalabik, Z. Y., Popaitoon, P., Chowne, J. A., \& Rayton, B. A. (2013). Work engagement as a mediator between employee attitudes and outcomes. The International Journal of Human Resource Management, 24(14), 2799-2823. doi: 10.1080/o9585192.2013.763844

Yeh, C. M. (2013). Tourism ivolvement, work engagement and job satisfaction among frontline hotel employees. Annals of Tourism Research, 42, 214-239. doi: 10.1016/j.annals.2013.02.002 